\title{
The potential role of desalination in managing flood risks from dam
} overflows: the case of Sydney, Australia

\author{
Andrea Turner $^{\mathrm{a}}$, Oz Sahin ${ }^{\mathrm{b}, \mathrm{c}}$, Damien Giurco ${ }^{\mathrm{a}}$, Rodney Stewart ${ }^{\mathrm{b}}$ and Michael Porter ${ }^{\mathrm{d}}$ \\ ${ }^{a}$ Institute for Sustainable Futures, University Technology Sydney, Australia \\ ${ }^{b}$ Griffith School of Engineering, Griffith University, Australia \\ ${ }^{\circ}$ Griffith Climate Change Response Program Griffith University, Australia \\ ${ }^{\mathrm{d}}$ Centre for Economics and Financial Econometrics Research, Faculty of Business and Law, \\ Deakin University, Melbourne, Australia
}

Corresponding author: Andrea Turner andrea.turner@uts.edu.au

\begin{abstract}
Shifting climate patterns are causing extreme drought and flooding across the globe. This combined with the world's burgeoning population and insatiable thirst for water requires water service providers to think differently about the limited resources they manage. In Australia, the severe drought at the beginning of the century caused dams to fall to record levels. In response, many state governments invested heavily in rain-independent supplies such as desalination to augment and diversify traditional sources. However, extreme rainfall soon followed the drought, filled reservoirs and caused flooding in many locations leaving billions of dollars worth of damage and new water infrastructure standing idle. This is the case in Sydney, where the new desalination plant is still not used and the potential for major flooding has raised concerns over the safety of the large population downstream of the dam. This paper explores the growing need to understand the relationship between drought, flooding and infrastructure optimisation. The paper focuses on Sydney to illustrate the application of a system dynamics model. The new model explores options for raising the dam wall, offering airspace to assist flood protection, in contrast to options to lower the dam full supply level and utilise idle desalination capacity to fill the water security gap created. The illustrative results, using publicly available data, find that by lowering the dam water levels and operating desalination, significant flood protection can be achieved at a similar cost to raising the dam wall. The paper demonstrates the importance of optimising existing and new water resources for multiple purposes and how system dynamics modelling can assist water service providers in these complex investigations.
\end{abstract}

\section{Key words}

Desalination, flood risk, system dynamics model, optimisation, urban water

\section{Introduction}

In recent years, areas including Australia (Turner et al., 2016), California within the US (Griffin and Anchukaitis, 2014; MWD, 2015), Sao Paulo in Brazil (Carvalho, 2015), many least developed countries in Asia (Miyan, 2014) and parts of China (Zhang and Zhou, 2015), have experienced severe drought. As we look to the future, the long-term effects of climate change are likely to result in a greater frequency of extreme droughts in many regions (IPCC, 2012; IPCC, 2014). This in combination with significant population rise will put additional pressure on the world's already limited water resources (McDonald et al., 2011). With these increasing pressures on our limited water resources, there is a need for greater use of alternative water supply sources (Gurung and Sharma, 2014).

At the same time more extreme flooding is being observed in many parts of the world and is likely to increase (Huber and Gulledge, 2011; Pittock, 2012; IPCC, 2014). Such flooding has had a significant impact with flood damage constituting approximately a third of the 
economic losses inflicted by natural hazards worldwide over the past few decades (Berz, 2005).

These extremes have had a significant impact in many countries, with Australia being a prime example of where drought was experienced for over a decade and quickly followed by significant flooding causing loss of life and severe damage (Turner et al., 2016). This combination of extreme droughts and floods and the trend towards increased urbanisation requires water service providers to think differently and to utilise infrastructure in a more productive, efficient and resilient way. Thus moving away from a fragmented and myopic perspective of water planning and management to a more integrated multi-dimensional systems perspective (Pandit et al., 2015; Turner et al., 2010; Kondili et al., 2010; Fane, 2005).

To help combat water scarcity, the vast opportunities of using desalinated seawater as a resilient rain independent urban water source are now being explored globally, with major focus in the Middle East, China, Australia and South America. This blending of ocean and rain-fed source water adds nuance to water planning and management and requires more sophisticated modelling of options to inform public debate given the major capital and operating costs incurred. There are currently over 18,000 desalination plants worldwide, with a production capacity of over 86 million $\mathrm{m}^{3} /$ day. These plants are located in over 150 countries and supply more than 300 million people ${ }^{1}$. Until recently, the key drawback of desalination plants has been their high energy intensity and associated unit cost $(A \$ / k L)$ to produce potable water when compared to other available water supply source options. However, recent development in desalination technologies, notably reverse osmosis, has meant that new plants are less energy intensive and have a lower production unit cost, making them viable bulk supply options in large coastal cities ${ }^{2}$.

Water security is one of Australia's greatest issues of concern (Beal et al., 2013). Australia has a vast coastline of $69,000 \mathrm{~km}$ (Galloway and Barr, 1979). Over $85 \%$ of the population live in coastal urban areas, with about $50 \%$ of the population currently located within $7 \mathrm{~km}$ of the shore and as many as 30\% within $2 \mathrm{~km}$ of the coast (Chen and McAneney, 2006). Desalination has therefore been seen as a huge untapped opportunity for urban water planning over the last decade whilst more traditional water sources (e.g. dams, groundwater and river abstraction) which are often rain-dependent, have fallen short during the worst national drought in Australian recorded history, the "Millennium" drought (Turner et al., 2016). Table 1 identifies the main desalination plants built in Australia since 2006, their capacity and costs.

\footnotetext{
1 http://idadesal.org/desalination-101/desalination-by-the-numbers/ (accessed 29/04/2016)

2 Desalination power costs have been inflated in public estimates by using expensive wind and solar energy cost estimates, rather than optimised power from the grid. Thus reported Australian desalination unit costs relative to the Middle East raise questions of comparable cost definition, since typically the energy efficiency of Australian plants has been as good as or better than other plants.
} 
Table 1: Key statistics for the main desalination plants in Australia (ATSE, 2012)

\begin{tabular}{|c|c|c|c|c|}
\hline Plants & Built & $\begin{array}{l}\text { Initial capacity } \\
\left(1 \times 10^{6} \mathrm{~m}^{3} / \mathrm{a}\right)\end{array}$ & $\begin{array}{c}\text { Capacity as a \% of annual } \\
\text { demand in 2009/10 }\end{array}$ & $\begin{array}{c}\text { Cost } \\
\left(1 \times 10^{6} \mathrm{~A} \$\right)\end{array}$ \\
\hline Perth I (Kwinana) & 2006 & 45 & 18 & 387 \\
\hline Gold Coast (Tugun)* & 2009 & 49 & 25 & 1,200 \\
\hline Sydney (Kurnell)* & 2010 & 90 & 18 & 1,890 \\
\hline Melbourne (Wonthaggi)* & 2012 & 150 & 43 & 3,500 \\
\hline Adelaide (Port Stanvac)** & 2012 & 100 & 80 & 1,830 \\
\hline Perth II (Binningup)"*** & 2012 & 100 & 40 & 1,400 \\
\hline
\end{tabular}

${ }^{*}$ Standby as at Jan $2015 ;$ ** planned standby $2015,{ }^{* * *}$ currently being expanded

These assets represent total sunk capital costs in excess of $A \$ 10$ billion. This high capital outlay places significant pressure on water pricing, which reflects infrastructure investment, and is recognised as being a major contributor to the rapid rise in water supply costs in Australia in recent years (PC, 2011).

Because unusually high rainfall has followed the investment in desalination, all of the desalination plants except Perth are currently on standby (as at 2015). Whilst some plants have been used for a limited time (i.e. Tugun in the Gold Coast predominantly as a backup source during flood events that caused water quality issues), such infrastructure now represents significant stranded assets that are not realising their full potential ${ }^{3}$.

The high rainfall experienced after the drought has caused severe flooding in several areas such as South East Queensland and Sydney. This has caused loss of life and billions of dollars worth of damage resulting in the need for State level inquiries (Queensland Floods Commission of Inquiry, 2012). Similar to the drought situation, much of the discourse on flooding currently focuses on major infrastructure solutions, that is, raising of dam walls to provide airspace to assist in flood protection (DPI, 2014). Whist this does provide a solution this comes at a high cost and does not make best use of the assets at hand, such as idle desalination.

This paper aims to provide an illustrative example of how such desalination plants can be utilised more effectively and assist in optimising the water infrastructure systems we have now. The analysis is based on a system dynamics model (SDM), developed and applied to other water planning illustrative examples in:

- South East Queensland (Sahin et al., 2014a) to explore scarcity pricing; and

- Melbourne (Porter et al., 2014, Sahin et al., 2014b, Scarborough et al., 2015) to explore rain-independent desalination versus more traditional rain-dependent dams in long term planning.

The analysis summarised in this paper focuses on examining how desalination could be used to ensure water security whilst other existing water infrastructure is used to increase flood protection. That is, a desalination plant is used to substitute supply lost if the full supply level (FSL) in the dam is dropped to such an extent that the dam provides both water security and capacity to hold a proportion of flows from flood events, thus reducing the risk of

3 Assets are often described as "stranded" when total revenues fail to cover total (fixed and variable) costs. However this does not mean plants should be idle, since marginal costs per ML can and frequently are lower than other sources, creating a need for sound asset optimisation based on marginal cost pricing and revenue generation. 
flood damage and assisting in improving evacuation timing. In this illustrative example the SDM uses publicly available information from Sydney and makes a constructive contribution to a contemporary policy problem, that is, exploring the merits (or otherwise) and costs of raising the dam wall to assist with flood mitigation arising from dam overflows due to heavy rain within the catchment versus other options. More broadly the illustrative example helps demonstrate the importance of optimising existing and new water resources for multiple purposes and how system dynamics modelling can assist water service providers in these complex investigations with multiple objectives.

The following sections provide a summary of the Sydney water supply system, current flooding issues and potential options where desalination could be considered to mitigate such flooding. It provides details of the SDM used for other cities and modified for the Sydney illustrative example, plus results of the modelling exercise and broader discussion on utilising desalination as part of the mix of water resources of a major city.

\section{The Sydney urban water context}

Before discussing the SDM and the results of the modelling, a brief outline of the Sydney water supply system is provided along with current flooding issues, recent government flooding investigations and potential options where desalination could be considered.

\section{Water sources}

The greater Sydney water supply system is complex with over 20 dams and a total dam capacity of 2,581,000 ML (WSAA, 2013). Despite being a complex system the 4.2 million people in Sydney and lower Blue Mountains are primarily supplied (80\%) by the large Warragamba dam $(2,027,000 \mathrm{ML}$ operating capacity) located $65 \mathrm{~km}$ west of Sydney. A secondary source, the Tallowa dam $160 \mathrm{~km}$ south of Sydney, is the key to the Shoalhaven scheme. Tallowa has a much smaller operating capacity of 7,500 ML (available for the Sydney and Illawarra system) but can provide flows into the Upper Nepean dams and Warragamba dam to top up the Sydney and Illawarra systems when Sydney dams reach a trigger level of $75 \%{ }^{4}$. This is particularly useful during drought conditions because when the Warragamba catchment suffers from extended low inflows due to dry weather conditions the Shoalhaven catchment often suffers less so.

As part of the Metropolitan Water Plans (MWP) for Sydney, which were first developed in 2004, revised in 2006, and reviewed in 2010 (NSW Office of Water, 2010), a more diverse portfolio has been developed to provide water services to the greater Sydney region. This includes a combination of dams, recycling, extensive water efficiency measures and now desalination.

The Sydney desalination plant has suffered from controversial decision-making outlined below. For this reason, more than any, it provides an interesting illustrative example of how such a desalination plant once constructed, and given relatively low marginal costs, could be used to help optimise the water resources system in a city for multiple purposes. The key criteria for the Sydney bulk water supply system are water security, system reliability, mitigating flood risk, environmental flows to rivers below the dam (not explored here), and acceptable water quality (not explored here).

${ }^{4}$ http://www.sca.nsw.gov.au/water/visit/warragamba-dam 


\section{The Sydney desalination plant}

The Sydney desalination plant began supplying water in early 2010 as part of a 2 year 'defects correction period'. At full capacity it is capable of producing $90 \mathrm{GL} / \mathrm{a}$, approximately $15 \%$ of current demand. The current design allows this capacity to be doubled (NSW Office of Water, 2010). However, as indicated earlier it represents one of several desalination plants around Australia that are currently in standby mode. The reasons for individual desalination plants being in standby mode are complex and case specific.

In 2004, the then NSW government committed $A \$ 4$ million to investigate the potential for desalination in Sydney. In 2005, the technologies and other options such as recycling and potential sites were investigated. By the end of that year, the planning for the plant construction was confirmed. However, in 2006, the plant was put on hold when the government adopted an innovative 'readiness strategy', to build only when dam levels fell below $30 \%$, that is, with the right approvals in place in sufficient time to build the plant before reaching dead storage (White et al., 2006). Whilst formally adopted by multiple stakeholders involved in the MWP process, the readiness strategy (part of a real-options process) was overtaken by political imperative. In early 2007, dam levels were dropping $0.5 \%$ per week. Prompted, in part, by concern of storage levels continuing to fall too close to the trigger level of $30 \%$ storage within the caretaker period of government ${ }^{5}$, a decision was made to tender for the design, construction and operation of the desalination plant (Giurco et al., 2014).

It has subsequently been acknowledged that if the call to tender for design, construction and operation had been split with hold and review points, the innovative 'readiness' strategy could have been preserved without the full cost of the pre-emptive build. In addition, not signing the full contract when the dam levels were at $57 \%$ would have avoided over commitment $(P C, 2011)$ and the $A \$ 1.9$ billion Sydney desalination plant sitting idle after the 'defects correction period' was complete.

The MWP, which sets out the mix of measures that secure the greater Sydney region water needs into the future is periodically reviewed. The current MWP is under review and should be released in 2015/16. The current plan relies on a mix of dams, recycling $(\sim 12 \%)$, desalination ( $15 \%)$ and water efficiency ( 25\%) (NSW Office of Water, 2010).

As shown in Figure 1 the existing desalination plant will become operational when total dam storage levels fall below $70 \%$ and continue to operate until total storage returns to $80 \%$. As can be seen, after various other measures such as restrictions, construction of a second desalination plant will be triggered when total dam storage levels drop to $30 \%$. Due to the existing infrastructure already in place, such as connecting pipework and roads servicing the plant, the second $90 \mathrm{GL} / \mathrm{a}$ desalination plant would likely cost less $\sim A \$ 1.5$ billion.

Another controversial aspect of the desalination plant is that even though the plant is currently in shutdown mode it costs the local utility (Sydney Water Corporation - SWC) customers over $A \$ 500,000 /$ day in "availability charges" (IPART, 2011). This is because the plant was sold to private investors, including a Canadian teachers pension plan, for $A \$ 2.3$ billion on a 50 year lease ${ }^{6}$. The investors are guaranteed an inflation-linked payment of $\mathrm{A} \$ 10$ billion from SWC whether the water is used or not. Additional fees such as a re-start fee of $A \$ 5.5$ million are payable to the investors when the plant is switched on (Malone,

5 that is, between when the state election was to be called and the date of election

${ }^{6}$ http://sydneydesal.com.au/about-sdp/ownership-structure (accessed 29/04/2016) 
2013). The Independent Pricing and Regulatory Tribunal of NSW (IPART) has reviewed and determined the prices that the owners of the plant (the Sydney Desalination Plant Pty Ltd) can charge customers for the period mid 2012 to mid 2017. These figures range from $A \$ 500,000 /$ day in long term shutdown mode to $A \$ 780,000 /$ day when the plant is in full operation mode (IPART, 2011).

This cost issue highlights the importance of examining opportunities to optimise the system and run the desalination plant full on, idle or under a mixed operating regime.

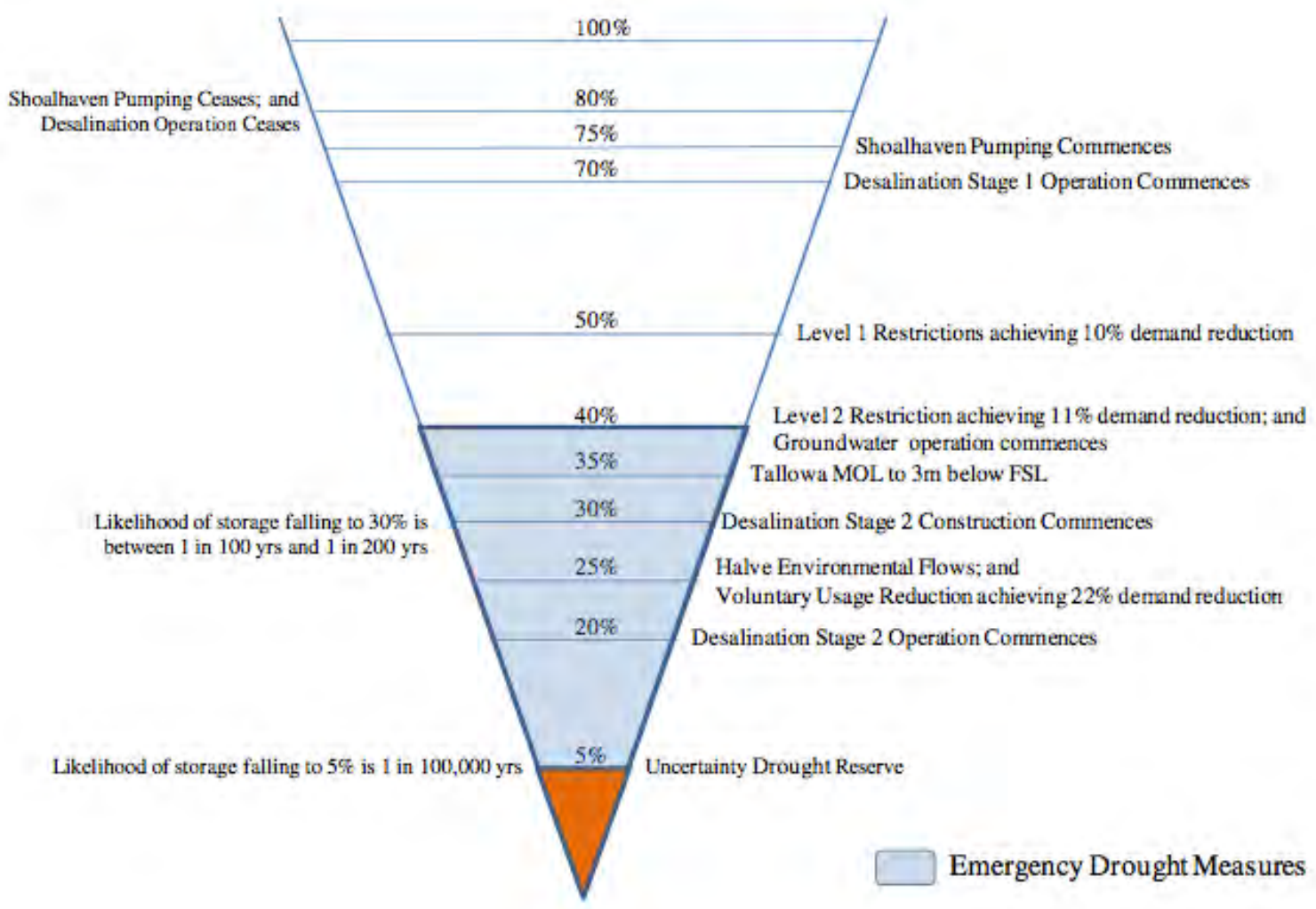

Figure 1 - Sydney's current water supply system operation (SKM, 2011)

\section{Recent flooding investigations}

Since the end of the drought investigations concerning the water supply system in Sydney have predominantly focused on flood mitigation issues. These have in part been due to the extensive flooding experienced in the south east region of Queensland in January 2011 and extensive flooding across south eastern Australia in 2012 which caused the Warragamba dam in Sydney to spill for the first time in 14 years. These experiences have highlighted the need for dams to play both a flood defence role as well as a water security role as the effects of climate uncertainty pan out.

In the floodplain below the Warragamba dam (refer to Figure 2) resides one of Australia's largest and most diverse local economies with an annual gross regional product of over A $\$ 95$ billion as at 2010/11 (DPI, 2014). However, within the floodplain approximately 73,000 people are currently living in areas prone to flooding. 13,000 of these are living in homes that could be severely damaged by a 1 in 200 chance per year flood where water levels could rise by $2 \mathrm{~m}$ (DPI, 2014). Despite this risk a large proportion of the future new homes and jobs projected in the Strategy for Sydney (NSW Government, 2014) are anticipated to be located 
within the floodplain. Due to the natural characteristics of the floodplain it is highly susceptible to floods with potential loss of life and property. Figure 3 shows the vulnerability of the region in terms of flood levels above the typical 1 in 100 flood level (used as the basis for default flood planning) compared to other Australian regions. Typically the probable maximum flood (PMF) in NSW rivers is less than $2 \mathrm{~m}$ higher than the 1 in 100 flood level. As can be seen in Figure 3 at the Richmond-Windsor location on the Warragamba floodplain, this is closer to a staggering $9 \mathrm{~m}$ (DPI, 2014).

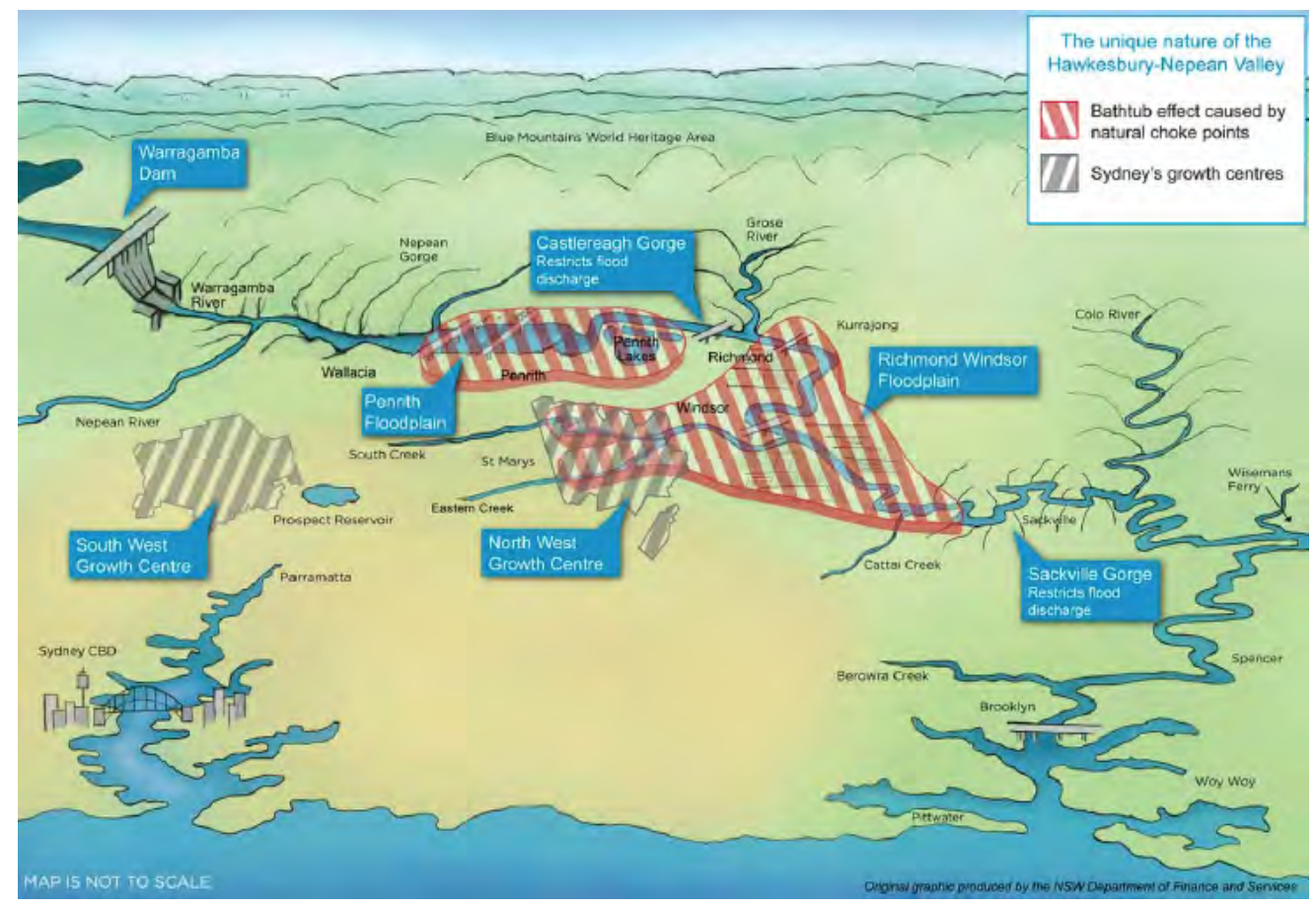

Figure 2 - Probable maximum flood inundation and growth areas downstream of the Warragamba dam (DPI, 2014)

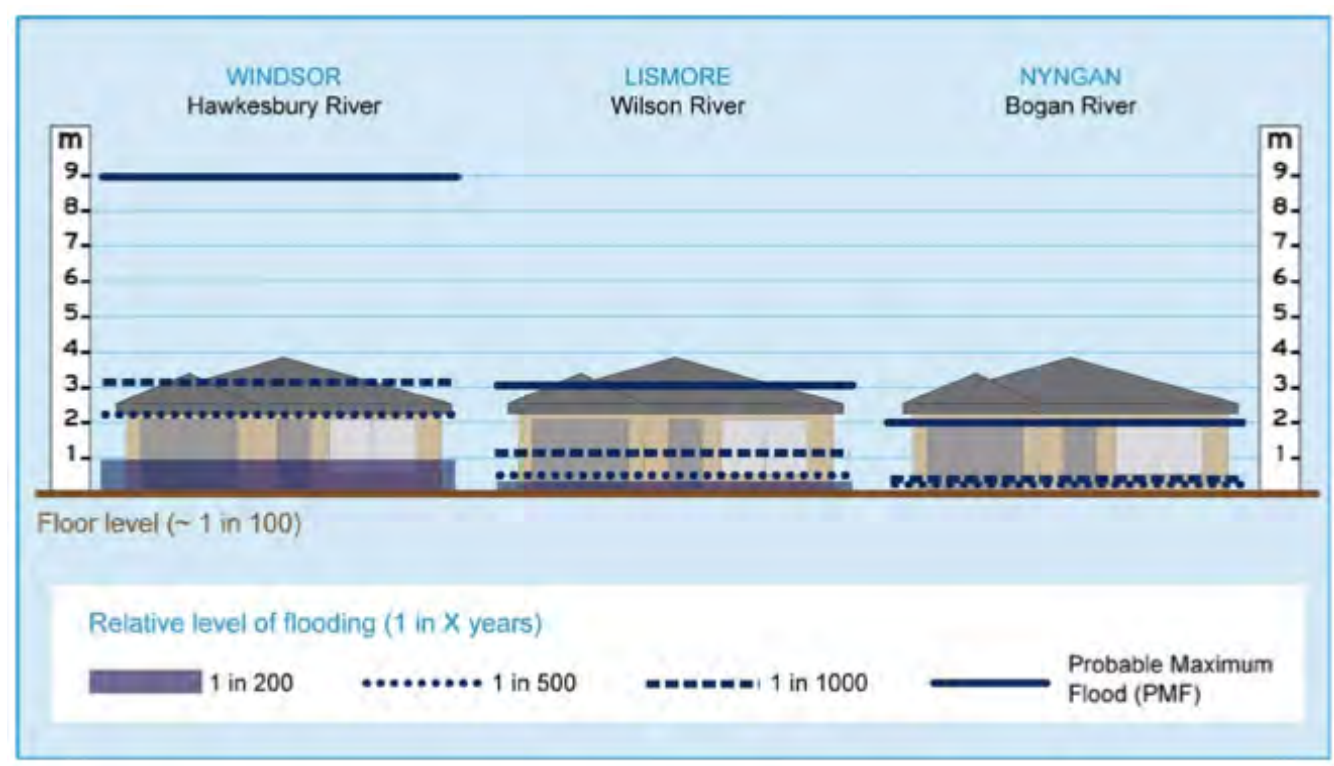

Figure 3 - Probable maximum flood levels for Richmond-Windsor area compared to other NSW rivers (DPI, 2014) 
In Sydney, it is estimated if a severe flood similar to 1867 (estimated to be in the range of a 1 in 200 to 1 in 500 chance per year but considered to be closer to 1 in 500 (DPI, 2014)) occurred today over 45,000 people would need to be evacuated with approximately $A \$ 4$ billion of damage. The low probability PMF (1 in 100,000 chance per year) would require 73,000 people to be evacuated and put over 20,000 homes at risk of failure (DPI, 2014). In such situations businesses would also be highly affected.

Table 2 shows the number of people and properties affected when estimates were conducted in 2011. These include an estimate of the number of properties that would have a cost of flood damage of greater than $A \$ 80,000$, which is a "threshold of affordability" above which many households would not be able to afford to recover. The table also contains estimates of direct and indirect flooding event damage. These costs include for example residential, caravans, commercial, motor vehicles, agriculture, roads and bridges, railways, water and sewerage, electricity, telephone, gas and oil, sand and gravel, defence, erosion and emergency services. The direct costs do not include those properties that are likely to "fail" therefore the estimates are considered conservative (Molino Stewart, 2012b).

Due to these significant potential impacts government led investigations in Sydney have primarily centred around (DPI, 2014):

- raising the dam wall at Warragamba by $+15 \mathrm{~m}$ or $+23 \mathrm{~m}$ to create flood storage capacity; and

- altering the operation of the dam or lowering the full supply level (FSL) to provide "airspace" to capture and store floodwaters

\section{Raising the dam wall}

The current dam capacity is 2,031,000 ML. Approximately $39 \%(795,000 \mathrm{ML})$ of this is above the crest of the main spillway, which is held by the dam's radial gates and drum gate. Due to the tapering shape of the dam a $+23 \mathrm{~m}$ dam wall extension would provide an enormous 2,800,000 ML of "additional" mitigation "airspace" (Molino Stewart, 2012b). The additional storage would provide flood protection for minor to PMF events. It would not eliminate the need to evacuate the populated floodplains below under more extreme floods (Molino Stewart, 2012a). It would however, reduce the costs of flood damage of which most are associated with greater than a 1 in 100 chance/year and when averaged out over the long term are mainly attributable to floods below a 1 in 500 chance/year as opposed to rarer events (DPI, 2014). It is also recognised however, that the dam extension would cause significant detrimental environmental damage upstream under more severe events (Molino Stewart, 2012b). This potential damage has not been documented extensively in the public domain and has therefore not been explored in this particular paper.

In 2015/16 the government is expected to release cost estimates for the various options identified above. In the absence of these, existing publicly available construction estimates from 1995 inflated to 2011 indicate that raising the dam wall by $+23 \mathrm{~m}$ could cost $\sim A \$ 350$ million. However, more recent pre-feasibility investigations (and associated press releases) indicate that the costs of options centred around raising the wall between $+15 \mathrm{~m}$ and $+23 \mathrm{~m}$ would be closer to between $A \$ 0.5$ to 1 billion (DPI, 2014; Hasham, 2014). 
Table 2 - Summary of flood events and associated estimated affected population and damage (DPI, 2014b; Molino Stewart, 2012b)

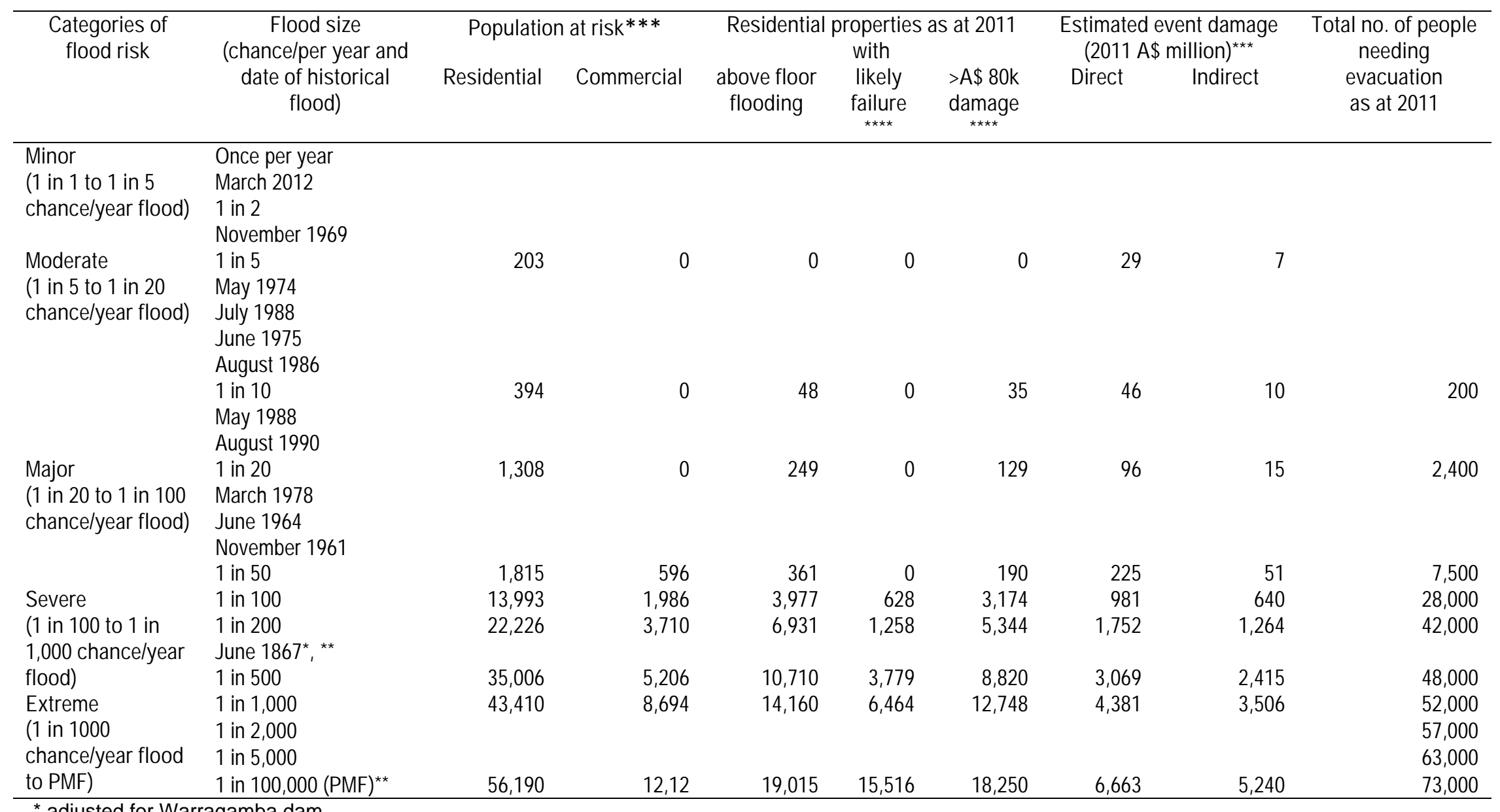

${ }^{*}$ adjusted for Warragamba dam

** estimated flows relating to the 1867 flood through the dam in $1867=2,200,000$ to $2,600,000 \mathrm{ML}$ and for a PMF $>6,000,000 \mathrm{ML}$

${ }^{* * *}$ excluding properties requiring rebuild but including residential, commercial, agriculture, infrastructure (e.g. roads) and services (e.g. telephone).

$* * * *$ subsets 


\section{Lowering the dam full supply level}

Viewing the dam management quite differently, lowering the FSL by up to $-12 \mathrm{~m}$ would provide up to $795,000 \mathrm{ML}$ of "airspace" for flood storage. The estimated cost to adjust existing pipework to accommodate this is $\sim A \$ 50$ to 70 million. Whilst lowering the FSL by $12 \mathrm{~m}$ would incur a cost, lowering the FSL by $-5 \mathrm{~m}$ would incur little or no cost as the dam frequently satisfactorily operates at this level already. Lowering the FSL by up to $-12 \mathrm{~m}$ provides potential flood storage capacity, however, it also represents a significant loss in dam capacity, up to 39\% (Molino Stewart, 2012b; DPI, 2014).

The government has also considered other combinations of options, such as adjusting the operating conditions of the dam so that water is released prior to a flood to create the flood storage capacity required when potential floods are anticipated. However, the option of releasing dam water prior to a flood has been considered difficult to predict with current metrological data and runs the risk of evacuating the potential community affected when rain and associated floods don't eventuate (DPI, 2014; Molino Stewart, 2012b).

\section{Potential use of desalination}

A scenario that appears to be less explored is where desalination can be used to replace the water security lost if dam levels are dropped to create airspace for flood storage.

Raising the dam by up to $+23 \mathrm{~m}$ has a high potential cost of up to $A \$ 1$ billion according to recent prefeasibility estimates, is logistically difficult, is likely to cause adverse environmental impacts upstream of the dam and will not rule out the need to evacuate the population of the floodplain during more extreme floods. Dropping dam levels by up to $-12 \mathrm{~m}$, is a low cost option ( $\sim \mathrm{A} \$ 50$ to 70 million) but is almost ruled out by government because water security could drop by up to $39 \%$.

However, the existing trigger levels for the desalination plant could be adjusted and/or the plant turned on when required to fill the security gap and recoup some of the water security lost by dropping the dam FSL at a marginal extra cost above that of the plant standing idle. By doing so the existing water infrastructure in Sydney could potentially be optimised to achieve both water security and a higher level of flood protection - potentially at a lower cost. This is explored below.

\section{System dynamics model}

Although the Sydney water system is complex and while many of the detailed figures required for such complex modelling are unavailable to the public, a SDM has been developed to explore how desalination in Sydney could potentially be used more effectively to substitute water lost if the dam FSL was lowered to assist in flood protection. Associated costs and benefits are also explored.

\section{The system dynamics model (SDM)}

As previously mentioned the SDM was first developed and applied in South East Queensland to explore water scarcity pricing (Sahin et al., 2014a). It was subsequently modified for Melbourne to explore rain independent desalination versus more traditional rain dependent dams in long term planning (Sahin et al., 2014b). Further details of the model can be found in these papers (Sahin et al., 2014a, Sahin et al., 2014b). 
The model has been modified for application in Sydney to explore flood mitigation potential. The SDM, using the Vensim ${ }^{\circledR}$ DSS (Ventana Systems, Inc, 2012) was built by identifying key variables, estimating assumed relationships between these variables and parameterising the relationships. The various components of the model are shown in Figure 4. The economic component of the modelling, that is, the comparison of costs of the various options considered is currently external to the SDM.

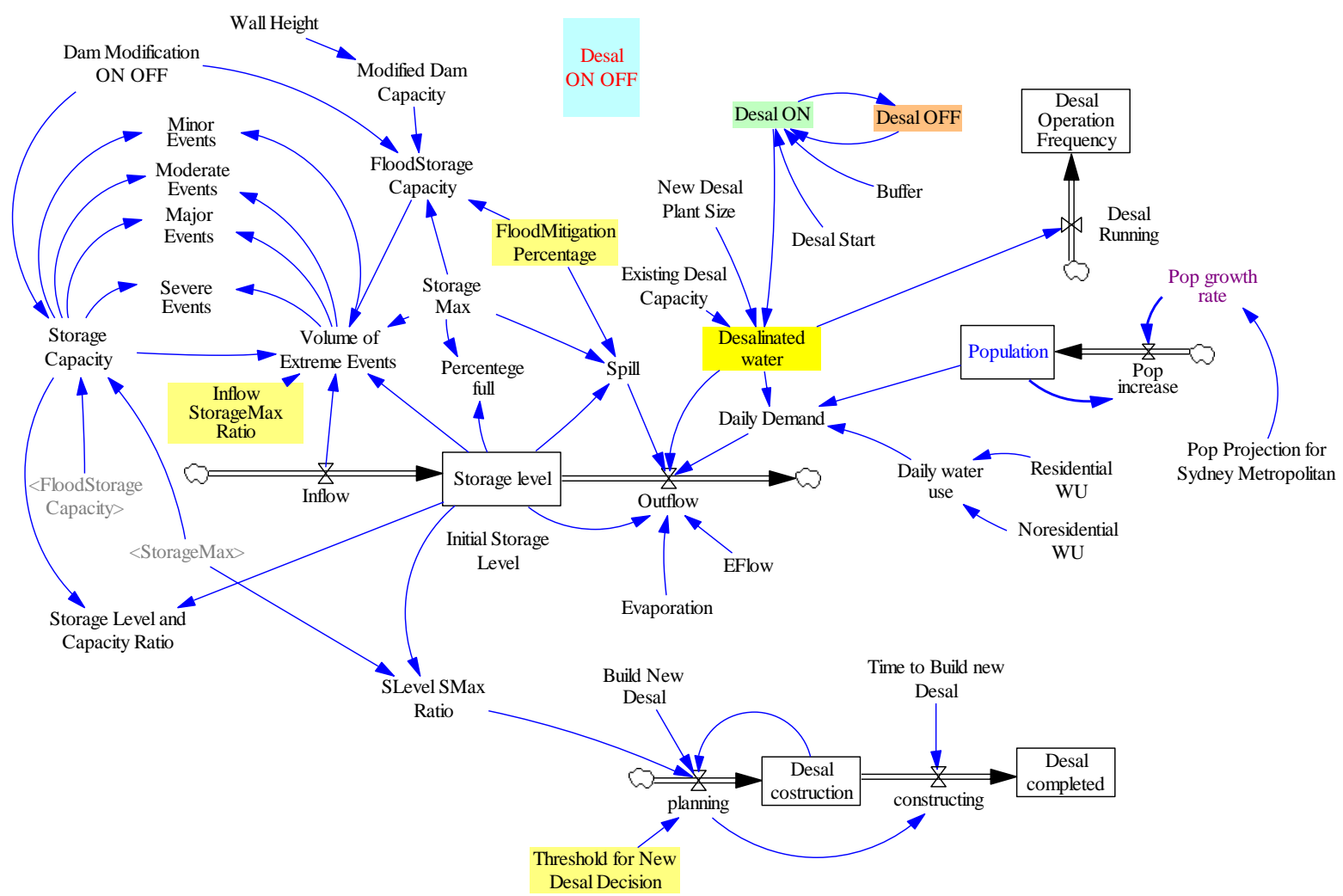

Figure 4 - System dynamics model components in Sydney example

\section{Options modelled}

To test whether using desalination is a viable option for replenishing water lost if the FSL were reduced, a series of options have been explored for a specific inflow-demand projection scenario (detailed below) for the next 25 years (2015 to 2039). The four key options modelled in the SDM entail either raising the dam wall by $+15 \mathrm{~m}$ or $+23 \mathrm{~m}$ or lowering the dam wall by $-5 \mathrm{~m}$ or $-12 \mathrm{~m}$. These options are shown in Table 3 and reflect the kinds of options the government is actually considering.

Existing infrastructure only $(E I O)$ has been modelled to reflect how the dam water levels might react to the inflow-demand projection scenario considered if no changes to the dam wall or FSL were made and no additional desalination (other than the existing desalination plant no.1 - DSP 1 - already in place) was built. Business as usual (BAU) has also been modelled and assumes no change to the dam wall or FSL but that all MWP triggers come into effect (e.g. desalination plant no. 2 - DSP 2 - is triggered to build when the dam levels hit $30 \%$ of current capacity and becomes operational when the dam levels hit $20 \%$ - refer to Figure 1). 
The four key options modelled $(+15 m,+23 m,-5 m$ and $-12 m)$ all assume that the existing MWP trigger levels for DSP 1 and DSP 2, as shown in Figure 1, remain in place except for the $-12 \mathrm{~m}$ option where the current MWP trigger levels for DSP 1 are actually lower than the $12 \mathrm{~m}$ option FSL and thus have had to be adjusted. Other key assumptions for the SDM are provided in Table 4 below.

Table 3 - Suite of options modelled

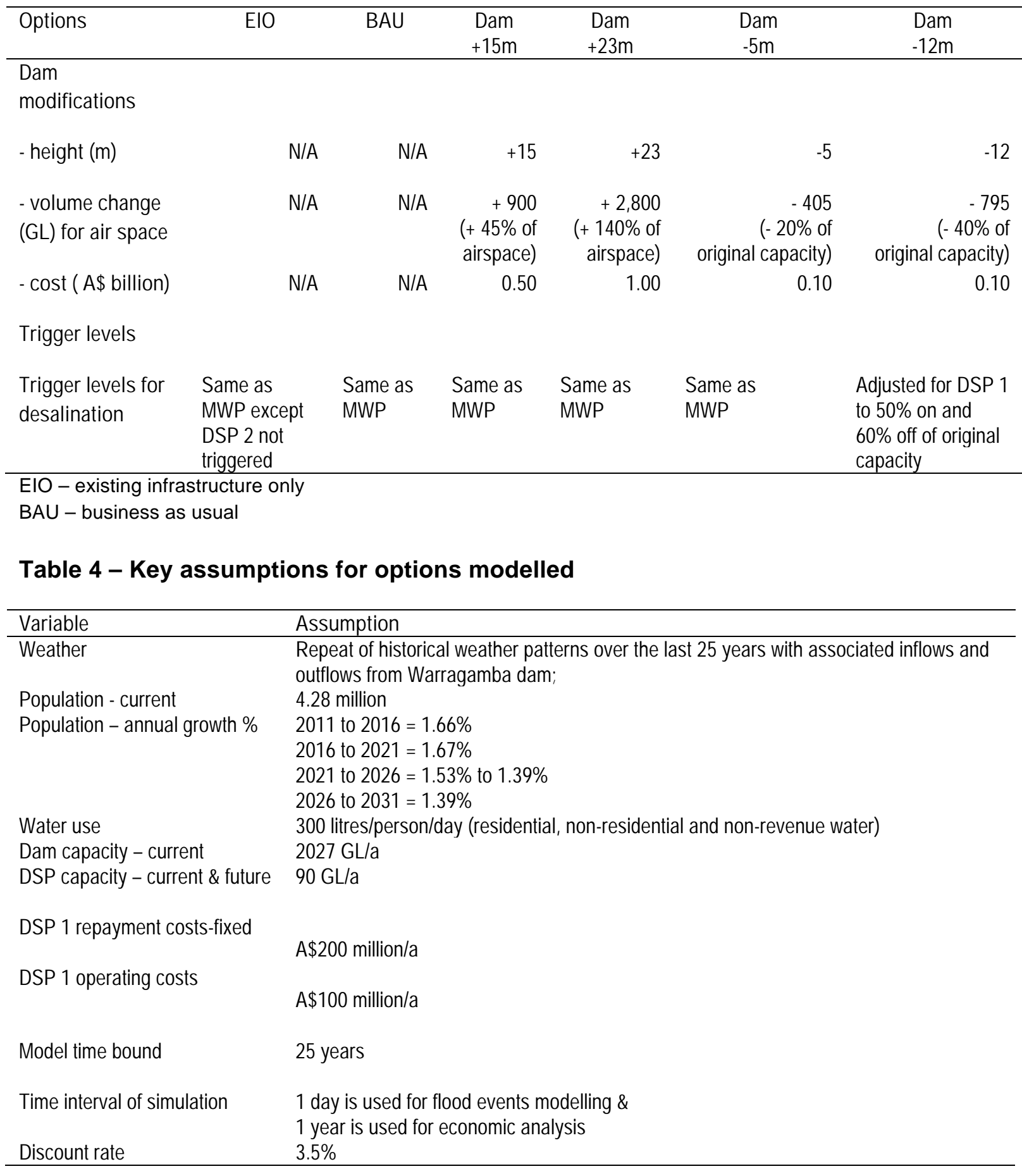




\section{Results}

In this section the results of the historical modelled inflows and associated dam levels are shown. This is followed by the outputs for the modelled options in terms of impacts on flooding, requirement for desalination and associated costs over the next 25 years.

\section{Inflows}

Figure 5 shows how modelled dam levels have varied since 1961. It also shows the frequency and severity of inflows that, depending on the storage levels of the dam, have led to flood events (minor to extreme). As can be seen there appear to be regular cyclical dry periods that have led to low dam levels. These appear to have increased in severity culminating in the Millennium drought during the 2000s where the dam level fell to $<35 \%$. The frequency of larger inflow events has significantly decreased over the last two decades leading to few flood events. Due to these dryer conditions the Warragamba dam did not spill over the period 1998-2012.

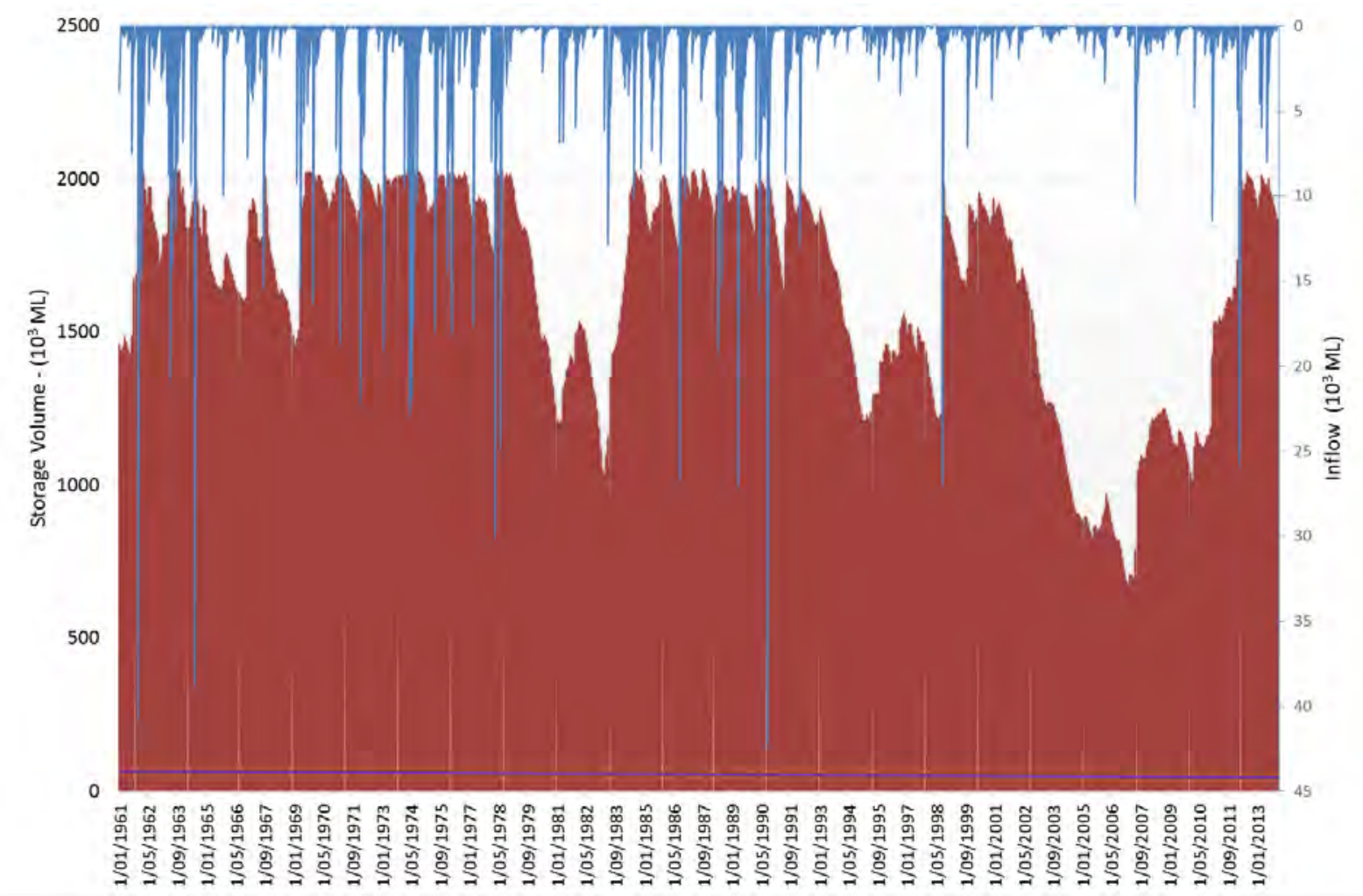

Figure 5 - Historical dam levels and inflows at Warragamba dam

\section{Inflow-demand projection scenario}

The last 25 years of historical weather patterns, that include flooding and extreme drought periods, have been used here to predict anticipated dam levels and flood events over the next 25 years. The projection period includes increased water demand from the increasing population. Whilst this scenario is only one of thousands of possible scenarios it is a tangible scenario that is valuable in demonstrating the SDM and options considered. Having developed the SDM, further modelling considering multiple inflow-demand projection scenarios and options to assist in exploring system optimisation are planned (but not explored here). 


\section{Modelling outputs}

As indicated in Section 2 it is acknowledged by the NSW government, currently investigating flooding issues associated with the Warragamba dam, that raising the dam wall even by $+23 \mathrm{~m}$ will not rule out the need to evacuate the population of the downstream floodplain or avoid the associated damage and threat to life during more extreme floods. With this in mind Table 5 summarises the modelling results of what could be expected under each of the options modelled with respect to flooding, use of the desalination plants (DSP 1, DSP 2 and potentially additional plants - DSP 3 and DSP 4 - to meet growing demand) and operating and capital infrastructure costs.

Table 5 Summary of modelling outputs

\begin{tabular}{|c|c|c|c|c|c|c|}
\hline & EIO & BAU & $\begin{array}{c}\text { Dam } \\
+15 m\end{array}$ & $\begin{array}{c}\text { Dam } \\
+23 m\end{array}$ & $\begin{array}{l}\text { Dam } \\
-5 m\end{array}$ & $\begin{array}{l}\text { Dam } \\
-12 m\end{array}$ \\
\hline \multicolumn{7}{|l|}{ Flood events } \\
\hline - minor & 21 & 21 & 0 & 0 & 0 & 0 \\
\hline - moderate & 3 & 3 & 0 & 0 & 0 & 0 \\
\hline - major & 6 & 6 & 0 & 0 & 1 & 0 \\
\hline - severe & 2 & 2 & 0 & 0 & 0 & 0 \\
\hline - extreme & * & * & * & * & * & * \\
\hline \multicolumn{7}{|l|}{ DSP 1} \\
\hline $\begin{array}{l}\text { Trigger levels for DSP } 1 \\
\text { operation }\end{array}$ & $\begin{array}{r}\text { Same as } \\
\text { MWP }\end{array}$ & $\begin{array}{r}\text { Same as } \\
\text { MWP }\end{array}$ & $\begin{array}{r}\text { Same as } \\
\text { MWP }\end{array}$ & $\begin{array}{r}\text { Same as } \\
\text { MWP }\end{array}$ & $\begin{array}{l}\text { Same as } \\
\text { MWP }\end{array}$ & $\begin{array}{r}\text { Adjusted to } 50 \% \\
\text { on and } 60 \% \text { off } \\
\text { (original capacity) }\end{array}$ \\
\hline $\begin{array}{l}\text { - no. of years active over next } 25 \\
\text { years }\end{array}$ & 19 & 16 & 16 & 16 & 22 & 18 \\
\hline \multicolumn{7}{|l|}{ DSP 2} \\
\hline $\begin{array}{l}\text { Trigger levels for DSP } 2 \\
\text { construction }\end{array}$ & $\mathrm{N} / \mathrm{A}$ & $\begin{array}{r}\text { Same as } \\
\text { MWP }\end{array}$ & $\begin{array}{r}\text { Same as } \\
\text { MWP }\end{array}$ & $\begin{array}{r}\text { Same as } \\
\text { MWP }\end{array}$ & $\begin{array}{r}\text { Same as } \\
\text { MWP }\end{array}$ & $\begin{array}{r}\text { Same as } \\
\text { MWP }\end{array}$ \\
\hline - when triggered to build & N/A & 2032 & 2032 & 2032 & 2032 & 2022 \\
\hline $\begin{array}{l}\text { - no. of years active over next } 25 \\
\text { years } \\
\text { DSP } 3\end{array}$ & $\mathrm{~N} / \mathrm{A}$ & 5 & 5 & 5 & 8 & 14 \\
\hline - when triggered to build & $\mathrm{N} / \mathrm{A}$ & 2034 & 2034 & 2034 & 2034 & 2024 \\
\hline $\begin{array}{l}\text { - no. of years active over next } 25 \\
\text { years } \\
\text { DSP } 4\end{array}$ & $\mathrm{~N} / \mathrm{A}$ & 3 & 3 & 3 & 6 & 12 \\
\hline - when triggered to build & $\mathrm{N} / \mathrm{A}$ & 2036 & 2036 & 2036 & 2036 & N/A \\
\hline $\begin{array}{l}\text { - no. of years active over next } 25 \\
\text { years } \\
\text { Costs (PV) }\end{array}$ & $\mathrm{N} / \mathrm{A}$ & 0 & 0 & 0 & 4 & N/A \\
\hline $\begin{array}{l}\text { - capital } \\
\text { dam modifications + DSPs } \\
\text { (A\$ billion) }\end{array}$ & $\mathrm{N} / \mathrm{A}$ & 2.19 & 2.67 & 3.15 & 2.19 & 2.06 \\
\hline - ongoing costs & 4.13 & 4.26 & 4.26 & 4.26 & 4.85 & 4.97 \\
\hline \multicolumn{7}{|l|}{$\begin{array}{l}\text { DSP1 repayment costs + } \\
\text { desalination operating costs } \\
\text { (A\$ billion) }\end{array}$} \\
\hline $\begin{array}{l}\text { - total costs } \\
\text { (A\$ billion) }\end{array}$ & 4.13 & 6.45 & 6.93 & 7.41 & 7.04 & 7.03 \\
\hline $\begin{array}{l}\text { EIO - existing infrastructure only } \\
\text { BAU - business as usual } \\
\text { BAU assumes MWP trigger level } \\
{ }^{*} \text { no PMF events included in the }\end{array}$ & & other & & yuired & & \\
\hline
\end{tabular}




\section{Discussion}

Detailed interpretation and discussion of the results of each option are provided below.

\section{EIO and BAU}

As can be seen from the modelling presented in Table 5 under EIO over the next 25 years (which relies only on the existing infrastructure, that is, the dam and DSP 1) we might expect to see:

- 21 minor, 3 moderate, 6 major and 2 severe events;

- DSP 1 first switched on in 2021 and running 19 of the 25 years modelled;

- DSP 1 repayment and operating costs (total present value costs PV $A \$ 4.13$ billion); and

- high flood damage costs potentially running into multiple billions of $A \$$ due to the number of potential moderate, major and severe events (refer to Table 2).

As shown in Figure 6, in this situation the dam levels run critically close to dead storage even with DSP 1 running 19 of the 25 years. This is due to the combination of low inflows and increased demand from the growing population.

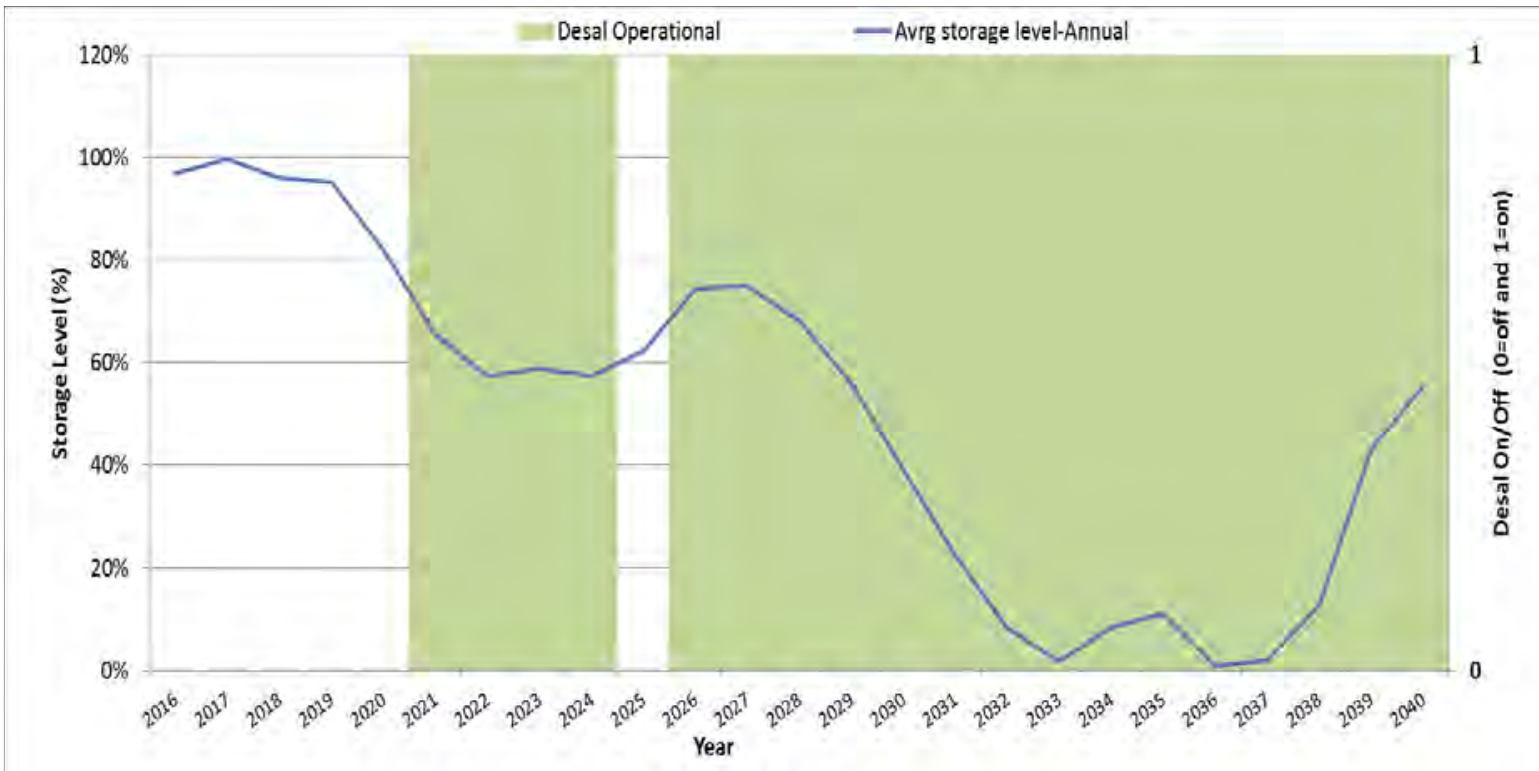

Figure 6- Existing infrastructure only option projected average dam storage levels and on/off operation of desalination plant 1

Under BAU that assumes construction of DSP 2 and other desalination plants as required under the current MWP trigger levels, we might expect to see:

- 21 minor, 3 moderate, 6 major and 2 severe events;

- DSP 1 first switched on in 2021 and runs 16 of the 25 years modelled;

- DSP 2 construction triggered in 2032 and runs 5 of the 25 years modelled;

- DSP 3 is also needed and construction triggered in 2034 (only 2 years later) because the demand at that time is just too high for the existing desalination plants to satisfy with the depleted dam under the sustained dry conditions;

- DSP 4 is also needed and construction triggered in 2036 (in another 2 years) as the situation remains the same but this desalination plant might not actually be used in 
the modelling period considered since normal rainfall conditions replenish the dam soon after it is constructed;

- total investment costs of PV $\mathrm{A} \$ 6.45$ billion (capital $\mathrm{A} \$ 2.19$ billion and ongoing $\mathrm{A} \$ 4.26$ billon); and

- high flood damage costs, as above, potentially running into multiple billions of $A \$$ due to the number of potential moderate, major and severe events (refer to Table 2).

As shown in Figure 7, in this situation the triggering and subsequent use of DSP 2 and other desalination plants as required assists in reducing the risk of the dam running into dead storage and facilitates greater recovery of storage levels but shows the dam still runs critically low.

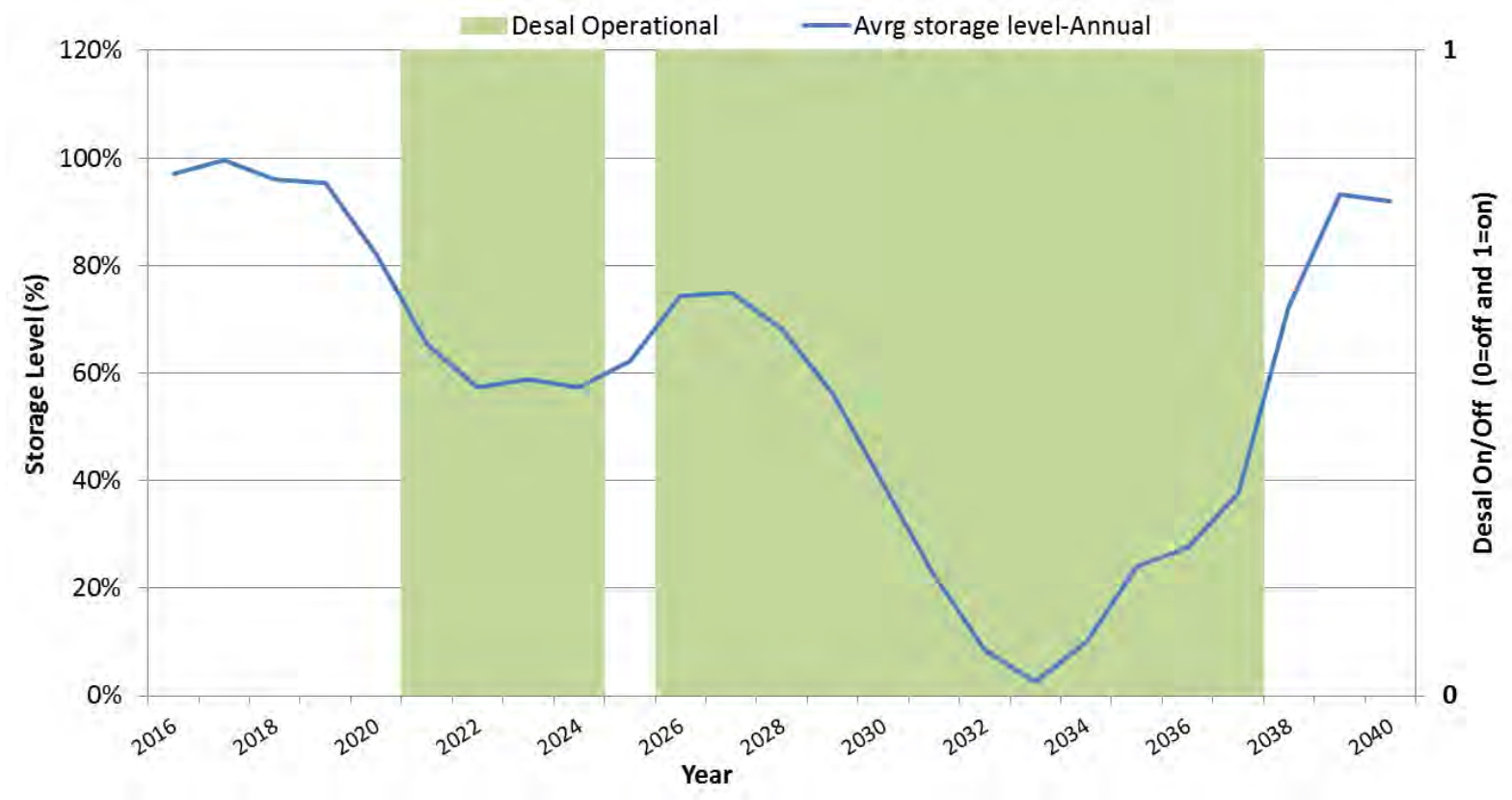

Figure 7 - Business as usual option projected average dam storage levels and on/off operation of desalination plants $1 \& 2$

This suggests that before even considering raising or lowering the dam wall for flood mitigation purposes (that may have implications on the security of supply) that the dam runs the risk of running into dead storage under this scenario (a repeat of the last 25 years of inflows occurs in combination with increased demand due to population rise). To mitigate such a risk additional supply and/or demand options plus adjustment of the dam trigger levels would be required to, for example, provide sufficient time to trigger and then build a desalination plant during low inflows as the population and associated demand grows over time. At current demand levels a trigger of $30 \%$ for construction and $20 \%$ for operation would be sufficient but in future as demand grows these trigger levels would need to be raised. As identified in Section 3, for the purposes of demonstrating the SDM, the MWP trigger levels have been kept as they are except in the case of the $-12 \mathrm{~m}$ option which had to be adjusted. 


\section{Options}

The four modelled options $(+15 m,+23 m,-5 m,-12 m)$ are used to test how raising the dam wall or lowering the dam FSL can reduce flood risk and associated damage costs and assume that depletion of security of supply is filled by building any number of required additional desalination plants. Of course this may not be the most economically viable solution in reality, as there may be lower cost solutions available. However, for the purposes of demonstrating the use of the SDM such option variables have been constrained.

In all four options $(+15 m,+23 m,-5 m,-12 m)$ the level of flood risk and associated damage costs, in this modelled scenario, is significantly mitigated except for PMF (which has not been modelled) and in the case of the $-5 \mathrm{~m}$ option where there is a risk of only 1 major flood occurring at the beginning of the 25 year projection period. Such a reduction in the threat of flooding and the associated damage costs is significant and suggests that some form of wall modification to provide flood protection should be undertaken.

\section{Raising the dam wall for flood protection}

Raising the dam wall by $+15 \mathrm{~m}$ or $+23 \mathrm{~m}$ will not actually affect when the desalination plants are triggered or run compared to BAU as the additional volume is only designated for flood protection purposes (i.e. 'airspace'). In these options we have assumed that the water security shortfall is made up by:

- DSP 1 first switched on in 2021 (the same as BAU) and runs 16 of the 25 years modelled;

- DSP 2 construction is triggered in 2032 and runs 5 of the 25 years modelled;

- DSP 3 is also needed and construction triggered in 2034 (only 2 years later) because the demand at that time is too high for the existing desalination plants to satisfy with the depleted dam under the sustained dry conditions; and

- DSP 4 is also needed and construction triggered in 2036 (in another 2 years) as the situation remains the same but this desalination plant might not actually be used in the modelling period considered since normal rainfall conditions replenish the dam soon after it is constructed.

Cessation of flood damage costs could be achieved for this particular scenario, potentially saving billions of $A \$$ due to the reduction of the number of potential moderate, major and severe flooding events.

Total investment costs for the $+15 \mathrm{~m}$ and $+23 \mathrm{~m}$ options are $\mathrm{PV} A \$ 6.93$. billion (A $\$ 2.67$ billion capital plus $A \$ 4.26$ billion ongoing) and $A \$ 7.41$ billion ( $A \$ 3.15$ billon capital plus $A \$ 4.26$ billion) respectively.

Figure 8 provides an overview of the average dam storage levels, the extent of operation of the desalination plants and the timing of the construction of the new desalination plants for the BAU, $+15 \mathrm{~m}$ and $+23 \mathrm{~m}$ options. 


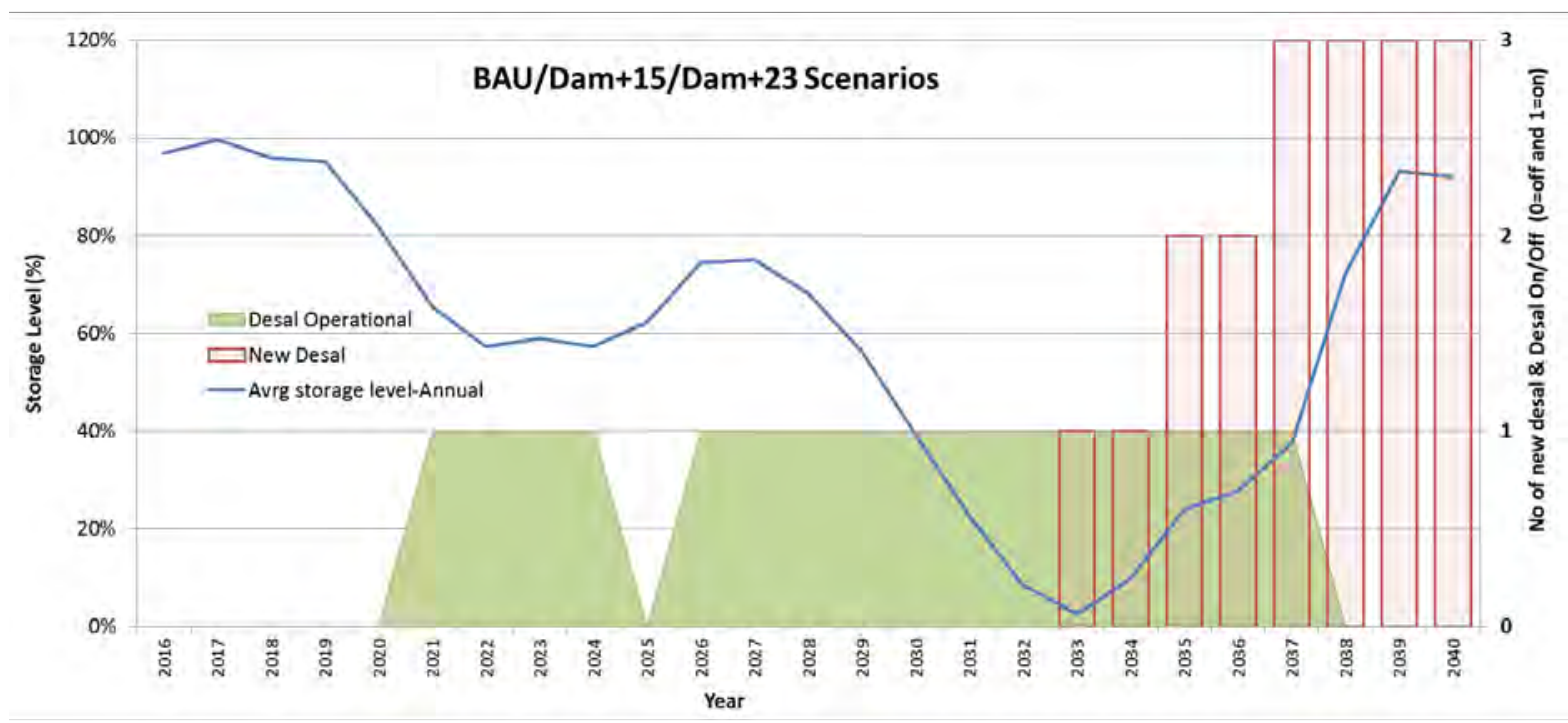

Figure 8 - Summary of dam levels, desalination plants operation and new desalination construction for the business as usual and raising dam wall options

\section{Lowering the dam FSL for flood protection}

Lowering the dam FSL by $-5 \mathrm{~m}$ or $-12 \mathrm{~m}$ will mean that there is less storage capacity available and potentially lower water security compared to BAU, meaning that more desalination plants may be needed and/or triggered earlier in an extended dry period.

Applying the SDM to the option of lowering the dam FSL by $-5 m$ ( $-20 \%$ by volume) results in the following utilisation and staging of desalination plants:

- DSP 1 first switched on in 2019 (2 years earlier than BAU) and runs 22 of the 25 years modelled;

- DSP 2 construction triggered in 2032 and runs 8 of the 25 years modelled;

- DSP 3 construction triggered in 2034 (only 2 years later) because the population demand at that time is just too high for the depleted dam and desalination plants to sustain under the dry conditions and runs for 6 years of the period modelled; and

- DSP 4 construction triggered in 2036 (in another 2 years) as the situation remains the same but the plant is potentially never actually used in the modelling period since normal rainfall conditions replenish the dam soon after it is constructed.

Virtual cessation of flood damage costs could be achieved for this particular scenario potentially saving billions of $A \$$ due to the reduction of the number of potential moderate, major and severe flooding events.

When comparing the lowered FSL $(-5 \mathrm{~m})$ to the option of raising the dam wall for flood protection (i.e. existing dam water storage capacity), there is still a need for a total of four desalination plants (DSP 1 to 4). The major difference is that they are triggered slightly earlier for the lowered FSL $(-5 \mathrm{~m})$ option and utilised more often.

Lowering the dam FSL by $-12 \mathrm{~m}$ ( $-39 \%$ by volume) was expected to significantly affect the water security compared to BAU and be expected to perform the worst out of the options in terms of security. However, due to the new volume being less than the MWP trigger levels for desalination operation (i.e. triggers of $70 \%$-on and $80 \%$-off according to Figure 1 ) the 
MWP operating rules were adjusted to $50 \%$-on and $60 \%$-off for this specific option. These changes to the dam capacity and MWP trigger levels had a profound influence on the requirement for new desalinated supply. Surprisingly, this scenario of lowering the dam FSL by $-12 \mathrm{~m}$ meant that fewer desalination plants were required overall as summarised below:

- DSP 1 first switched on in 2019 (2 years earlier than BAU) and runs 18 of the 25 years modelled;

- DSP 2 construction triggered in 2022 (10 years earlier than BAU) and runs 14 of the 25 years modelled;

- DSP 3 construction triggered in 2024 (only 2 years later) and runs 12 of the 25 years modelled; and

- no DSP 4 triggered in the 25 year period modelled.

Cessation of flood damage costs could be achieved for this particular scenario potentially saving billions of $A \$$ due to the reduction of the number of potential moderate, major and severe flooding events.

The total investment costs for the $-5 \mathrm{~m}$ and $-12 \mathrm{~m}$ options are PV $\mathrm{A} \$ 7.04$ billion (A $\$ 2.19$ billion capital plus $\$ A 4.85$ billion ongoing) and $P V A \$ 7.03$ billion ( $\mathrm{A} \$ 2.06$ billion capital plus $A \$ 4.97$ billion ongoing) respectively.

\section{Optimisation}

Figure 9 shows that in the $+15 \mathrm{~m},+23 \mathrm{~m}$ and $-5 \mathrm{~m}$ options, even with the additional desalination plants DSP 2 to 4, the dam storage levels become dangerously low. However, because the original MWP triggers are adjusted and DSP $2 \& 3$ are brought on earlier, the $12 \mathrm{~m}$ option provides sufficient security to ride out a drought situation similar to a repeat of the Millennium drought but with an even higher population.

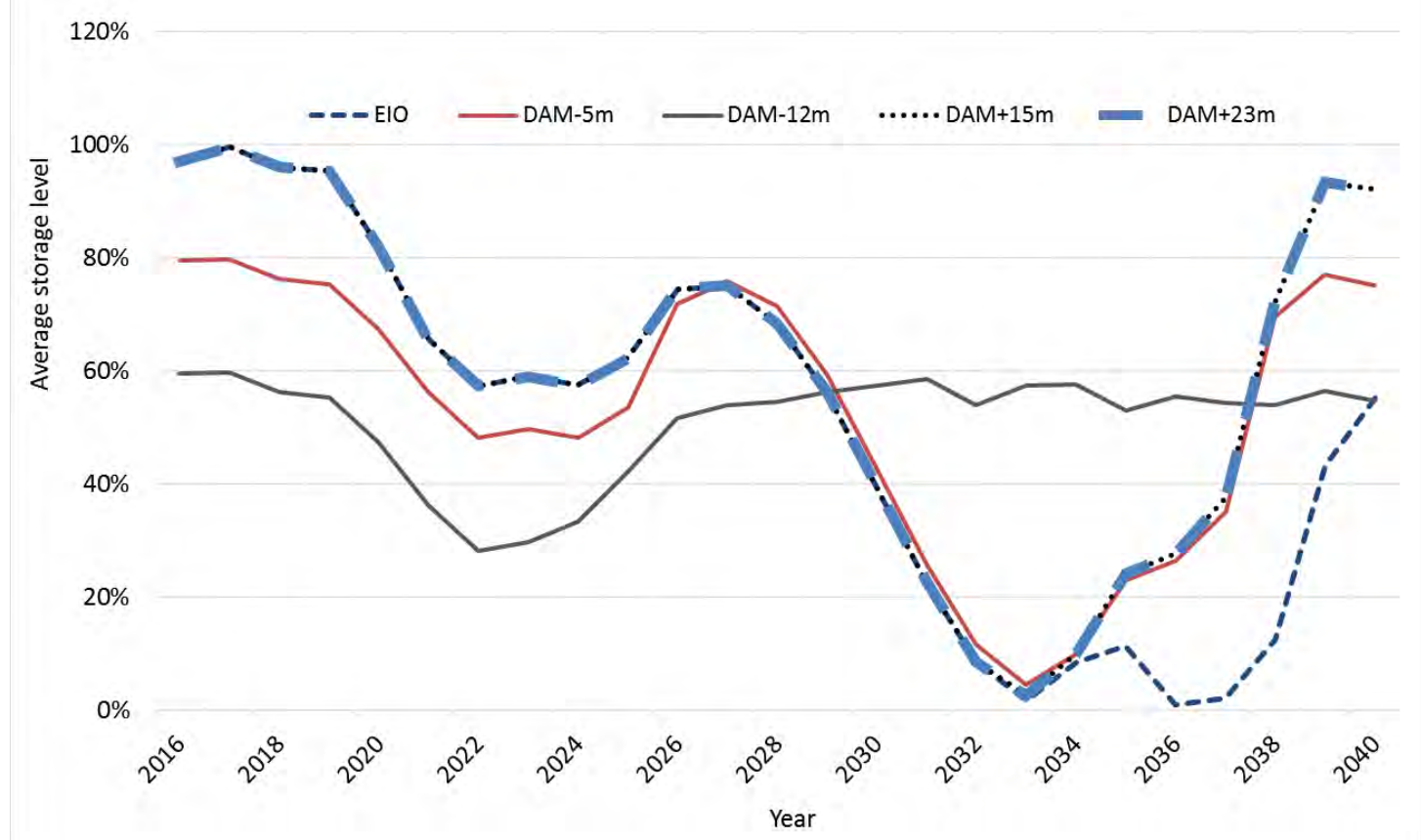

Figure 9 - Projected dam depletion curves for various options (note the business as usual option follows the same line as $+15 \mathrm{~m}$ and $+\mathbf{2 3 m}$ but has been omitted for clarity) 
Table 6 provides a summary of the key features of the options modelled. As can be seen significant expenditure is required for BAU to provide security of supply even without modification of the dam for flood management purposes. The $+23 \mathrm{~m}$ is unsurprisingly the most expensive of the options considered. However, the $+15 m,-5 m$ and $-12 m$ options group closely together in terms of total costs but with varying capital and operating expenditure underlying these costs. All four options modelled provide a significant reduction in flood risk.

Table 6 - Summary of the key features of the options modelled

\begin{tabular}{lccccccc}
\hline & $\begin{array}{c}\text { Trigger } \\
\text { level for } \\
\text { desal } \\
\text { operation }\end{array}$ & $\begin{array}{c}\text { Threshold for } \\
\text { new desal } \\
\text { construction }\end{array}$ & $\begin{array}{c}\text { Ave storage } \\
\text { level } \\
\text { (annual) }\end{array}$ & $\begin{array}{c}\text { No of years } \\
\text { storage } \\
\text { below 40\% }\end{array}$ & $\begin{array}{c}\text { No of } \\
\text { new } \\
\text { desal }\end{array}$ & $\begin{array}{c}\text { Desal } \\
\text { operating } \\
\text { freq. (years) }\end{array}$ & $\begin{array}{c}\text { Discounted } \\
\text { total costs } \\
\text { (A\$ billion) }\end{array}$ \\
\hline EIO & $70 \%$ & N/A & $50 \%$ & 9 & 0 & 19 & 4.13 \\
BAU & $70 \%$ & $30 \%$ & $59 \%$ & 8 & 3 & 16 & 6.45 \\
$+\mathbf{+ 1 5 m}$ & $70 \%$ & $30 \%$ & $59 \%$ & 8 & 3 & 16 & 6.93 \\
$\mathbf{+ 2 3 m}$ & $70 \%$ & $30 \%$ & $59 \%$ & 8 & 3 & 16 & 7.41 \\
$\mathbf{- 5 m}$ & $70 \%$ & $30 \%$ & $52 \%$ & 7 & 3 & 22 & 7.04 \\
$\mathbf{- 1 2 m}$ & $50 \%$ & $30 \%$ & $51 \%$ & 4 & 2 & 18 & 7.03 \\
\hline
\end{tabular}

Assumed desalination plant size $250 \mathrm{ML} / \mathrm{d}$

* includes DSP 1 repayment

This brings into sharp focus the question of how to optimise the existing infrastructure to avoid flood risk and maximise security plus call on new supply expansion options when required at the lowest cost to society.

The scenario chosen, that is, inflow projections assuming a repeat of the last 25 years of inflows is repeated with increased demand due to population rise, is just one scenario. The four options chosen to test, which reflect what government have been considering, have various sub options that could be examined through extensive sensitivity analysis, including consideration of:

- various storage inflow patterns;

- different population growth rates;

- demand reduction as efficiency and source substitution regulations for new buildings come into effect and urban density intensifies;

- new MWP trigger levels for the use of existing infrastructure and demand management measures as well as when to trigger new supply and demand-side options that will need to change over time; and

- the size of new infrastructure such as desalination.

These along with other variables such as the height to raise the dam or lower the FSL together with additional dam management procedures can be tested to examine how to minimise flooding risk, optimise the use of existing infrastructure and bring on board new options - all at lowest cost to society. 


\section{Conclusions}

This paper explores the potential trade-offs between flood risk and water security, the use of existing and new infrastructure, and the associated cost implications, using a system dynamics model.

In short, the results contrast (i) higher cost options that involve raising the dam wall by $+15 \mathrm{~m}$ or $+23 m$ to provide "airspace" for potential flood mitigation with (ii) lower cost options that involve lowering the FSL in the dam by $-5 \mathrm{~m}$ or $-12 \mathrm{~m}$ to provide potential flood mitigation but at a risk of compromising water security. The results show that under the scenario modelled, that is, a repeat of the last 25 years of inflows but including projected growth and spread of population in vulnerable areas, that under BAU there are likely to be numerous flooding events ranging from minor to severe. These flood events have the potential to cause billions of dollars of damage, lost income and loss of life. With the current development within the dam flood plain this implies that some form of dam wall modification is urgently required to avoid such risk. As raising the dam wall will be logistically challenging, and potentially take several years to construct, reducing the FSL should be considered a viable option.

Even with such flooding over the period examined the EIO option (using DSP 1) and BAU option (triggering the build and use of DSP 2 and additional desalination plants according to the MWP) show that the existing infrastructure cannot cope with the inflow scenario modelled. With the increased demand from the growing population the dam comes dangerously close to dead storage before new inflows replenish supplies. In reality the dams would not reach this point and additional supply and/or demand options would be triggered as required. However, in three of the options modelled $(+15 m,+23 m$ and $-5 m)$ where three additional desalination plants are triggered to replenish security lost due to flood mitigation and/or more extreme climatic conditions - the options still can't cope with the increased population demand and run the risk of reaching dead storage before being replenished by inflows. Surprisingly only the $-12 \mathrm{~m}$ option, which has a cost comparable to the $+15 \mathrm{~m}$ and $5 \mathrm{~m}$ options, is able to provide both flood protection and water security. This is primarily because the MWP triggers have had to be adjusted to accommodate the $39 \%$ loss in dam capacity and brought the need for construction of DSP 2 and DSP 3 forward. Whilst seemingly expensive to do so it provides an effective insurance policy and obviates the need for DSP 4 in the modelling conducted. This option shows that by adjusting the current MWP trigger levels greater optimisation of existing and new infrastructure can be achieved which can potentially mitigate flood risk and water security issues.

Whilst the modelling was conducted with limited publicly available data and the system is inherently complex with distinct interactions and feedback loops, it nevertheless demonstrates the power of such modelling and in the case of the $-12 \mathrm{~m}$ option, surprising results. With further refinement, the SDM has enormous potential to assist in testing hundreds of different scenarios, options and sub options to help determine the optimal use of existing and new infrastructure for both flood protection and water security. Such tests can also illustrate total cost implications and additional impacts on environmental flows. The illustrative example explores the growing need to understand the relationship between drought, flooding and infrastructure optimisation. It demonstrates the importance of optimising existing and new water resources for multiple purposes and how system dynamics modelling can assist water service providers in these complex investigations as the effects of climate change pan out. 


\section{Acknowledgements}

This research is part of a study on desalinated water in Australian bulk water supply networks, funded by a grant from the National Centre of Excellence in Desalination Australia (NCEDA) to Deakin University, in a project jointly managed with Griffith University, and with technical cooperation from AECOM Ltd.

\section{References}

ATSE, 2012. Sustainable Water Management: Securing Australia's future in a green economy. Report of a study by the Australian Academy of Technological Sciences and Engineering (ATSE), Melbourne, Victoria.

Beal, C.D., Stewart, R.A., Fielding, K., 2013. A novel mixed method smart metering approach to reconciling differences between perceived and actual residential end use water consumption. J. Clean. Prod. 60, 116-128. http://dx.doi.org/ 10.1016/j.jclepro.2011.09.007.

Berz, G., 2005. Weather Catastrophes and Climate Change: Is There Still Hope for Us? Münchener Rückversicherungs Gesellschaft (Munich Re), Munich, Germany, 1-264.

Carvalho, L., 2015, June 26. Megacity drought: Sao Paolo withers after dry 'wet season'. The Conversation. https://theconversation.com/megacity-drought-sao-paulo-withers-afterdry-wet-season-42799 (accessed 29.04.16).

Chen, K., McAneney, J., 2006. High-Resolution Estimates of Australia's Coastal Population. Geophys. Res. Lett. 33 (L16601). http://dx.doi.org/10.1029/2006GL026981.

Fane, S. A., 2005. Planning for Sustainable Urban Water: systems-approaches and distributed strategies. Institute for Sustainable Futures, University of Technology, Sydney.

Galloway, R.W., Bahr, M.E., 1979. What is the length of the Australian Coast? Aust. Geogr. 14(4), 244-247. http://dx.doi.org/10.1080/00049187908702768.

Giurco, D.P., Turner A., Fane S., White S.B., 2014, Desalination for urban water: changing perceptions and future scenarios in Australia, Chem. Eng. Trans. 42, 13-18. http://dx.doi.org/10.3303/CET1442003.

Griffin, D., Anchukaitis, K.J., 2014. How unusual is the 2012-2014 California drought? Geophys. Res. Lett. 41 9017-9023. http://dx.doi.org/10.1002/2014GL062433.

Gurung, T.R., Sharma, A., 2014. Communal rainwater tank systems design and economies of scale. J. Clean. Prod. 67, 26-36. http://dx.doi.org/10.1016/j.jclepro.2013.12.020.

Hasham, N., 2014, March 12. Warragamba Dam wall raising divides experts on $\$ 1$ billion cost, efficiency. The Sydney Morning Herald.

http://www.smh.com.au/environment/warragamba-dam-wall-raising-divides-experts-on-1billion-cost-efficiency-20140311-34kfd.html (accessed 29.04.16).

Huber, D., Gulledge, J., 2011. Extreme weather and climate change. C2ES Center for Climate Change and Energy Solutions, Arlington, VA.

http://www.c2es.org/publications/extreme-weather-and-climate-change (accessed 29.04.16). 
IPART, 2011. Prices for Sydney Desalination Plant Pty Limited's Water Supply Services for the period to 30 June 2017, Water - Issues Paper. Report prepared by the Independent Pricing and Regulatory Tribunal of New South Wales, Sydney, NSW.

IPCC, 2012. Managing the Risks of Extreme Events and Disasters to Advance Climate Change Adaptation, Special Report of the Intergovernmental Panel on Climate Change. Cambridge University Press, Cambridge, UK and New York, NY.

IPCC, 2014. Freshwater resources, in: Climate Change 2014: Impacts, Adaptation, and Vulnerability. Part A: Global and Sectoral Aspects, Working Group II Contribution to the Fifth Assessment Report of the Intergovernmental Panel on Climate Change. Cambridge University Press, Cambridge, UK, 229-270.

Kondili, E., Kaldellis, J.K., Papapostolou, C., 2010. A novel systemic approach to water resources optimisation in areas with limited water resources. Desalination. 250(1), 297-301. http://dx.doi.org/10.1016/j.desal.2009.09.046.

Malone, U., 2013, September 2013. New South Wales desalination plant deal to cost consumers $\$ 10$ billion over 50 years. ABC News. http://www.abc.net.au/news/2013-0927/nsw-desalination-plant-deal-costing-customers-\$10-billion/4985168 (accessed 29.04.2016).

McDonald, R.I., Green, P., Balk, D., Fekete, B.M., Revenga, C., Todd, M., Montgomery, M., 2011. Urban growth, climate change, and freshwater availability. Proceedings of the National Academy of Sciences of the United States of America, 108(15), 6312-6317.

Metropolitan Water District of Southern California (MWD), Responding to drought: Regional Progress Report. An annual report to the California State Legislature on Achievements in Conservation, Recycling, and Groundwater Recharge. Los Angeles, CA.

Miyan, M.A., 2015. Droughts in Asian Least Developed Countries: Vulnerability Sustain. Weather Clim. Extrem. 7, 8-23. http://dx.doi.org/10.1016/j.wace.2014.06.003.

Molino Stewart, 2012a. Hawkesbury-Nepean Flood Damages Assessment - Addendum Report: Answers to Recent Questions. Report prepared for Infrastructure NSW by Molino Stewart Pty Ltd, Parramatta, NSW.

Molino Stewart, 2012b. Hawkesbury-Nepean Flood Damages Assessment - Final Report Infrastructure NSW. Report prepared for Infrastructure NSW by Molino Stewart Pty Ltd, Parramatta, NSW.

NSW Department of Primary Industries (DPI), Office of Water, 2014. Hawkesbury-Nepean Valley Flood Management Review Stage One Review Report, NSW.

NSW Government, 2014. A Plan for Growing Sydney. Report prepared by NSW Government Department of Planning and Environment, Sydney, NSW.

http://www.planning.nsw.gov.au/ /media/Files/DPE/Plans-and-policies/a-plan-for-growingsydney-2014-12.ashx.

NSW Office of Water, 2010. 2010 Metropolitan Water Plan, Department of Environment, Climate Change and Water, Sydney, NSW. 
Pandit, A., Minné, E.A., Li, F., Brown, H., Jeong, H., James, J.C., Newell, J.P., Weissburg, M., Chang, M.E., Xu, M., Yang, P., Wang, R., Thomas, V.M., Yu, X., Lu, Z., Crittenden, J.C., 2015. Infrastructure ecology: an evolving paradigm for sustainable urban development. J. Clean. Prod. http://dx.doi.org/10.1016/j.jclepro.2015.09.010.

Pittock, B., 2012, February 24. Droughts and flooding rains: climate change models predict increases in both. The Conversation. https://theconversation.com/droughts-and-flooding-rainsclimate-change-models-predict-increases-in-both-5470 (accessed 29.04.16).

Porter, M.G., Downie, D., Scarborough, H., Sahin, O., Stewart, R.A., 2014. Drought and desalination: Melbourne water supply and development choices in the twenty-first Century. Desalin. Water Treat. 55(9), 2278-2295. http://dx.doi.org/10.1080/19443994.2014.959743.

Productivity Commission (PC), 2011. Australia's Urban Water Sector, Report No. 55, Final Inquiry Report, Canberra, ACT.

Queensland Floods Commission of Inquiry, 2012. Final Report. Report prepared for the Queensland Government, Brisbane, QLD.

http://www.floodcommission.qld.gov.au/_data/assets/pdf_file/0007/11698/QFCI-FinalReport-March-2012.pdf.

Sahin, O., Siems, R.S., Stewart, R.A., Porter, M.G., 2014a. Paradigm shift to enhanced water supply planning through augmented grids, scarcity pricing and adaptive factory water: a system dynamics approach. Environ. Model. Softw. 1-14. http://dx.doi.org/10.1016/j.envsoft.2014.05.018.

Sahin, O., Stewart, R.A., Porter, M.G., 2014b. Water security pricing and reverse osmosis: a system dynamics approach, J. Clean. Prod. 88, 160-171.

http://dx.doi.org/10.1016/j.jclepro.2014.05.009.

Scarborough, H., Sahin, O., Porter, M., Stewart, R., 2015. Long-term water supply planning in an Australian coastal city: dams or desalination? Desalination. 358, 61-68.

http://dx.doi:10.1016/j.desal.2014.12.013.

SKM 2011. Water Supply System Model and Yield Review 2009/2010 - Volume 1: Main Report prepared by SKM for the Sydney Catchment Authority, Sydney, NSW.

Turner, A., White, S., Chong, J., Dickinson, M.A., Cooley, H., Donnelly, K., 2016. Managing Drought: Learning from Australia. Report prepared by the Alliance for Water Efficiency, the Institute for Sustainable Futures, University of Technology Sydney and the Pacific Institute for the Metropolitan Water District of Southern California, the San Francisco Public Utilities Commission and the Water Research Foundation, Sydney, NSW. Retrieved from: http://www.allianceforwaterefficiency.org/AWE-Australia-Drought-Report.aspx.

Turner, A., Willets, J., Fane, S., Giurco, D., Chong, J., Kazaglis, A., White S., 2010. Guide to Demand Management and Integrated Resource Planning. Report prepared by the Institute for Sustainable Futures, University of Technology, Sydney for the National Water Commission and the Water Services Association of Australia, Inc., Sydney, NSW.

Ventana Systems, Inc, 2012. Vensim DSS, Version 6.0b. http://www.vensim.com/. 
White, S., Campbell, D., Giurco, D., Snelling, C.M., Kazaglis, A., Fane, S.A., 2006. Review of the Metropolitan Water Plan: Final Report. Report prepared by the Institute for

Sustainable Futures, University of Technology Sydney, ACIL Tasman and SMEC Australia, Sydney, NSW.

Water Services Association of Australia (WSAA), 2013. Dams Information Pack One. Melbourne, VIC and Sydney, NSW.

https://www.wsaa.asn.au/sites/default/files/publication/download/WSAA\%20Dams\%20Fact\% 20Sheet\%20Information\%20Pack.pdf.

Zhang, L., Zhou, T., 2015. Drought over East Asia: a review. J. Clim. 28, 3375-3399. http://dx.doi.org/10.1175/JCLI-D-14-00259.1. 